Global Conferences Series:

Social Sciences, Education and Humanities (GCSSSEH), Volume 2, 2019

The $2^{\text {nd }}$ International Conference on Sustainable Development \& Multi-Ethnic Society

DOI: https://doi.org/10.32698/GCS.01101

\title{
The Applications of Historical Thinking Skills in Teaching and History Learning: Between Rhetoric and Reality
}

\author{
Jordan Maria ${ }^{1}$, Anuar Ahmad ${ }^{2} \&$ Mohd Mahzan Awang $^{3}$ \\ ${ }^{1}$ Ministry of Education, MALAYSIA \\ ${ }^{23}$ Faculty of Education UKM, MALAYSIA \\ E-mail: jordanmariaukm@gmail.com
}

\begin{abstract}
The applications of Historical Thinking Skills in teaching and History learning have become more attention among researchers in Malaysia after the Standard Curriculum of Secondary Schools for History education was launched by the Ministry of Education in 2016. Historical Thinking Skills are consisting five skills such as understanding the chronology, discovering historical evidence, making interpretation, imagination, and rationalization that can help the students cognitively to understand the process of using the historical information, it's including deciphering context, perspective, point of view, and the perceived facts to understand the past or thinking like as historian. Furthermore, Historical Thinking Skills have been more important as the appropriate skills in history learning, especially for students on how to learn the history subject authentically and dynamically than only memorizing historical facts and events. On top of that, Historical Thinking Skills were compulsory skills which are used in teaching and history learning who must be mastered by students and also teachers in Malaysia with desired the students' aspirations in which embodied in the Malaysian Education Development Plan (2013-2025) can be achieved which is to develop thinking skills among them. As a history teacher, the applications of Historical Thinking Skills must be fostered to their students in which also was emphasized in Standard Document for Curriculum and Assessment of History subject. However, the applications of Historical Thinking Skills in teaching and History learning having many issues, problems, and challenges that acquired by researchers whether it becomes more rhetoric or reality which be the points in our discussion.
\end{abstract}

Keywords: Historical Thinking Skills, Teaching and History Learning, Issues, Problems and Challenges.

\section{Introduction}

Copyright $\odot$ 2019, the Authors. Published by Redwhite Press. This is an open access article under the CC BY-NC license (http://creativecommons.org/licenses/by-nc/4.0).
For decades, some educators believe on what Dewey's opinion in his book Democracy and Education which observed that "All which the school can or need do for their 
students, as far as their minds are concerned is to develop their ability to think" (Dewey, 1916 cited in Schleifer, 1997). Education should be developing students' thinking, not by telling them what to think, rather by helping them to find their paths to meaning. If thinking is about how students make sense of things, then developing their thinking skills will help them gain more out of learning and out of life. Thinking skills is one of the student's aspiration that embodied in Malaysian Education Development Plan (PPPM) from 2013 to 2025. In History education context, History curriculum in Malaysian secondary schools has changed particularly after the launch of the PPPM (20132025) with the new curriculum that known as Standard Curriculum of Secondary School (Ministry of Education, 2016) which is one the manifestation of the implementation of the PPPM (2013-2025) which emphasizes the importance of thinking skills among the students in secondary schools (Ministry of Education, 2013). This new curriculum aims to produce students who do not only have the historical knowledge and civic values but also to develop their thinking skills (Department of Curriculum Development, 2016). History education was upgraded from an elective subject in 1989 to a core subject and in 2013 the government decided to include History subject as another compulsory subject to be passed in the Malaysian Certificate of Education (SPM) examination, which is a compulsory examination for students in form five (aged 17). Besides, History subjects is a subject that can stimulate historical thinking among the students (Centre of Curriculum Development, 2002). Therefore, History education is a core subject which can develop students' thinking skills which also to educate Malaysian to be good citizens to fulfill students' aspiration in PPPM (2013-2025).

History education has been discussed and improved as presented in the Standard Curriculum of Secondary School (SCSS). SCSS for History education was introducing about History Thinking Skills as an appropriate skill to learn History subject correctly and instructed as in History textbook which needs to incorporate in teaching and History learning. The applications of Historical Thinking Skills in teaching and History learning are pragmatic ways to foster Historical Thinking among students (Department of Curriculum Development, 2016). Historical Thinking Skills is one of the elements in History discipline that was recognized as the best approach to teach and learn History subjects (Centre of Curriculum Development, 2002) since over the years. However, after the government decided on History subject as a compulsory subject that needs to be pass in the SPM examination, but the results of SPM for History subjects still did not show the way of thinking such as Historical Thinking among the students. The percentage of History subjects in the SPM examination at the national level still showed a modest percentage of pass for that paper (Malaysian Examination Board, 2018) if compared from year to year since 2013. The main reason for this problem is that students do not have their ability to use thinking skills when they are answering questions categorized as high-level questions such as the question that encourages them to evaluate historical events in the past. Furthermore, the applications of Historical Thinking Skills in teaching and History learning become more rhetoric due to some issues which create problems and bring the challenges to educate our students on History education. So, the purpose of this concept paper is to give clear understanding on the applications of Historical Thinking Skills in teaching and History learning and showing whether it incorporated as a rhetoric or reality in teaching and History learning.

\section{Historical Thinking Skills}

Historical Thinking Skills is a form of cognitive process (Curriculum Development Centre, 2002). Historical Thinking Skills also defined as a process using historical information, including deciphering context, perspective, point of view, and the perceived facts to understand the past (Siti Hawa Abdullah, 2008). Yeager and Foster (2001) see Historical Thinking Skills as "a powerful tool for understanding history" and "dominant skills in understanding history". These skills help students to discern the significant from the insignificants facts. Historical Thinking Skills are vital intellectual skills (Rosy, 2016; Bain, 2000) that needs to be incorporated into the teaching and History learning by teachers as to achieve the goal of History education in Malaysia. However, other researchers in the field of History discipline have defined the term "historical thinking" as simply "thinking like a historian" (Wineburg, 2001; Cooper, 2000). This definition implies that as person's effort and ability to place historical information or a historical document, including interpretations, meanings, and context, into the social setting in which was created. Likewise, professional historians use the process of defining value, objectivity, bias, sources, and content when interpreting and evaluating historical information or primary source documents (Cuban, 2001; Seixas \& Peck 2004; Wineburg, 2004).

The applications of Historical Thinking Skills in teaching and History learning aim to generate the process of critical thinking among students through the evaluation of historical evidence by linking the historical events with past and present that enable tehm to apply lessons learned in the context of their lives (Abdul Razaq Ahmad 2010; Rosy, 2014; Siti Hawa Abdullah, 2008). Besides, the applications of Historical Thinking Skills in teaching and History learning could help the students to enhance their History Knowledge, Skills, and alues as suggested in the SCSS. To acquire Historical Thinking Skills, students need to think critically and creatively to increase the probability of a desirable 
outcome (Fahim \& Masouleh, 2012). The use of phrases such as "historical thinking" also refers to a process of using Critical Thinking Skills or High Order Thinking Skills in History learning. Paul (1994) identified two types of critical thinking. First, the weak sense of critical thinking which means the students have learned the skills but have not applied them in real situations. Second, the strong sense of critical thinking where students only have learned the skills but also incorporated those skills in their life's activities. Hence, students with a strong sense of critical thinking will acquire both Historical Thinking Skills and High Order Thinking Skills as required in students' aspirations which embodied in the PPPM (2013 2025).

The History curriculum listed five skills of Historical Thinking Skills which covers Understanding Chronology, Explore Historical Evidence, Interpretation, Imagination, and Rationalize (Department of Curriculum Development, 2016) as described below;

\subsection{Understanding Chronology}

Understanding chronology involves activities to encourage students to learn and understanding the chronology of past events based on the layout of the date, the place, the actors and the events. This skill helps students to answer four of the $\mathrm{W}$ in the $5 \mathrm{~W} 1 \mathrm{H}$ principle that is the When, Where, Who and What. Understanding chronology allows students to acquire the historical facts.

\subsection{Exploring Historical Evidence}

Having acquired the historical facts, students are expected to discover evidence to proof the correctness of the facts. There is abundant evidence that can be searched of. Exploring historical evidence involves the skill to identify primary and secondary sources. These are the sources to be studied and investigated, in order to look for the correctness of the facts encountered in the history. In fostering this skill history teachers need to find, read and analyse materials related to the topics to be taught before providing such materials to the students. This procedure suggests the use of the textbook alone is no longer enough to equip students this skill.

\subsection{Interpretation}

Making interpretation is a skill trying to offer meaning to the historical facts that have been proven authentic by the evidence. This skill is to answer the last $\mathrm{W}$ in the $5 \mathrm{~W} 1 \mathrm{H}$ principle, which is the Why. By providing proofs for the existence of the historical event students' understanding can be increased. History teachers should train and encourage students to give reasons for the occurrence of any historical event based on the evidence obtained using the previous skill.

\subsection{Imagination}

Bridging the historical facts requires the skill of imagining things. This skill encourages students to put themselves in the events being studied and allows them to visualize themselves in the event. This exercise release students' empathy towards the people at the time of the event. So, they are able to appreciate what they are having now. The imagination skill helps students to answer the $1 \mathrm{H}$ of the $5 \mathrm{~W} 1 \mathrm{H}$ principle that is the How.

\subsection{Rationalize}

Having imagined themselves in the past events, students should be able to rationalize the existence of the historical facts. This skill demonstrates students' ability to make sound judgment of the events and thoughtful linkages between the historical events with the present and future events. It gives students the whole meaning of the events in the past, and its implication to todays and future events. Rationalize skill enables students to solve problems based on the historical events associated with todays and future events.

Each of the skills explained above is interrelated. Historical Thinking Skills is a combination of five skills that need to be acquired to make the History subject interesting and meaningful to the life of the students. These skills offer the answer to the $5 \mathrm{~W} 1 \mathrm{H}$ principle. Therefore, teachers should travel with their students to understand the historical chronology, explore the evidence, interpret the facts based on the evidence, and use imagination to have empathy and rationalize its meaning to understand the meaning of History in today's and future life.

\section{The Applications of Historical Thinking Skills in the Teaching and History Learning}

Historical Thinking Skills are not skills that acquired naturally by students. It is not a generic skill. It must be learned and mastered by teachers before they can prepare students towards its mastery (Warren, 2007; Wineburg, 2000). There are some arguments about the applications of Historical Thinking Skills in teaching and History learning. Normally, History teachers are still using Teacher-Centered learning in History class. Unfortunately, History class never has Student-Centered learning which enables students to incorporate the Historical Thinking Skills in their learning. Besides, some explanations of the historical information by History teachers heavily referred from the History textbook and do note writing that based on textbook is the part of the student's common activities that often happening in the History class. All these activities were not helping in terms of encouraging students towards the Historical Thinking. 
One of the activities that enable students to develop the Historical Thinking Skills is questioning. Felder and Brent (2003) and Fink (2004) suggest History teachers should ask higher level questions to their students. Such questions lead students to think inside and outside of the box. Their suggestion shows one of the ways to cultivate Historical Thinking Skills in teaching and History learning is through questioning techniques. This suggestion has also been supported by Cooper and Dilek (2004). According to Fisher (1998) questioning skills is an important component in every lesson. Furthermore, questioning encourages interaction between teachers and students as well as the interaction among the students themselves. During the interaction, students can develop their ability to think critically. Therefore, History teachers are needed to master the skills of questioning so that they can incorporate the Historical Thinking Skills in their teaching and History learning among students.

For the applications of Historical Thinking Skills in the teaching and History learning among students, History teachers must acquire the skills of questioning as presented in Bloom's Taxonomy (1956). This taxonomy categorized into six levels; the knowledge, understanding, application, analysis, synthesis and evaluation levels. Of the six levels, the knowledge and understanding levels are classified as lower order thinking skills. This question is usually intended to test students' understanding of the topics that have been learned. To answer such questions students are only encouraged using their recalling skills. This is the types of question commonly asked by teachers. In terms of Historical Thinking Skills, these levels of question encourage the applications of the Historical Thinking Skills basics. The other remaining levels, the application, analysis, synthesis and evaluation are the highest level of question. These questions are meant to test students' highest thinking skills such as to interpret, to imagine and to rationalize the facts learned. If such questions are asked by teachers, then the Historical Thinking Skills advance is incorporated into the students.

White (2002) gave additional ideas to Blooom's taxonomy to be in line with the need to effectively incorporating Historical Thinking Skills in the teaching and History Learning. Table 1 shows the Bloom's Taxonomy and White's additional ideas. When it is analysed, Bloom's Taxonomy was designed to assess students' understanding of the facts presented in the teaching and learning process. White's additional ideas are not only emphasizing on students' understanding of the facts, but also promoting students' thinking skills. By implementing White's ideas, the effort to apply the Historical Thinking Skills advance in the teaching and History learning can be upheld. Besides that, the thinking maps also help clarifies qualities as well as show relationships between events. The research studied by Salleh S.S \& Ismail R. (2013), Mohd Mahzan Awang, Abdul Razaq Ahmad \& Mohd Muhaimi Abdul Rahman (2014), and Mazlan Husin, Mohd Mahzan Awang \& Anuar Ahmad (2017) showed the effectiveness of using mind maps for History education. Apart from that, learning and facilitation aided by information and communication technology (ICT) is one of the effective methods of teaching that are often used by teachers today. According to Norakma Mohd Daud, Abdul Razaq Ahmad and Noria Munirah Yakub (2015) learning is based on higher order thinking skills (HOTS) in the teaching and learning of history shows that HOTS can serve as a platform to attract students learn history and make it a subject of interest.

Table 1 Bloom's Taxonomy and White's Ideas

\begin{tabular}{|c|c|c|}
\hline Level & Bloom's Taxonomy & $\begin{array}{c}\text { White's } \\
\text { Additional Ideas }\end{array}$ \\
\hline Knowledge & $\begin{array}{l}\text { Scan and recall the } \\
\text { things that have been } \\
\text { learned before. } \\
\text { Keywords: Reflect, } \\
\text { State, Label, List, } \\
\text { Match, Name, Read, } \\
\text { Produce, Record, } \\
\text { Select, Highlight, } \\
\text { Define and Write. }\end{array}$ & $\begin{array}{l}\text { Not limited to } \\
\text { ideas, events, } \\
\text { names and date. } \\
\text { Make } \\
\text { interpretation } \\
\text { whether } \\
\text { historians } \\
\text { generally agreed } \\
\text { / objected. }\end{array}$ \\
\hline Understanding & $\begin{array}{l}\text { Understanding the } \\
\text { meaning of the } \\
\text { materials. } \\
\text { Keywords: Classify, } \\
\text { Convert, Describe, } \\
\text { Discuss, Anticipate, } \\
\text { Explain, Generalize, } \\
\text { Give Examples, } \\
\text { Illustrate, restate (based } \\
\text { on their own } \\
\text { interpretation), } \\
\text { formulate, to detect and } \\
\text { understand. }\end{array}$ & $\begin{array}{lr}\text { Increasing } & \text { a } \\
\text { person's ability to } \\
\text { assess the } \\
\text { implications, } \\
\text { effects and } \\
\text { chronology }\end{array}$ \\
\hline Application & $\begin{array}{l}\text { Using previous } \\
\text { knowledge in the } \\
\text { current situation, to } \\
\text { solve problems, and to } \\
\text { get the best alternative. } \\
\text { Keywords: Use, } \\
\text { Demonstrate, } \\
\text { Calculate, Complete, } \\
\text { Illustrate, Show, }\end{array}$ & $\begin{array}{lr}\text { To see } & \text { the } \\
\text { chronology } & \text { of } \\
\text { historical } & \text { events } \\
\text { and } & \text { its } \\
\text { difference. }\end{array}$ \\
\hline
\end{tabular}




\begin{tabular}{|c|c|c|}
\hline & $\begin{array}{l}\text { Relate, Change, } \\
\text { Classify, Construct and } \\
\text { Operate. }\end{array}$ & \\
\hline Analyses & $\begin{array}{l}\text { Distribute the pieces of } \\
\text { information, to } \\
\text { evaluate the relevance } \\
\text { of the information in } \\
\text { making conclusions, } \\
\text { identifying motives or } \\
\text { causes, making } \\
\text { inferences and finding } \\
\text { evidence to support } \\
\text { generalizations. } \\
\text { Keywords: Analyze, } \\
\text { Categorize, Compare, } \\
\text { Distinguish, Relate, } \\
\text { Differentiate, } \\
\text { Prioritize, Identify and } \\
\text { Divide. }\end{array}$ & $\begin{array}{l}\text { To clarify cause } \\
\text { and effect, "Why } \\
\text { and What will } \\
\text { happen". } \\
\text { To enhance } \\
\text { students' } \\
\text { intellectual skills } \\
\text { by requiring } \\
\text { them to make } \\
\text { their own } \\
\text { analysis to } \\
\text { criticize others' } \\
\text { analysis. }\end{array}$ \\
\hline Synthesis & 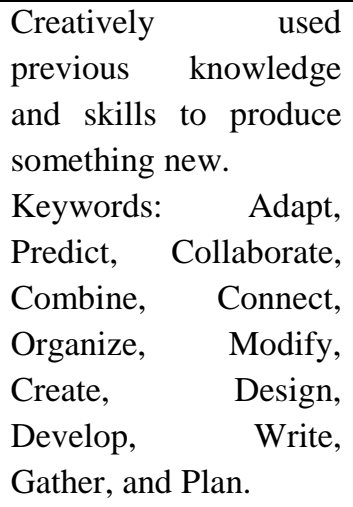 & $\begin{array}{l}\text { Issuing ideas } \\
\text { from general } \\
\text { knowledge. } \\
\text { Organizing and } \\
\text { separating facts, } \\
\text { and building } \\
\text { general } \\
\text { conclusion from } \\
\text { the facts. }\end{array}$ \\
\hline Evaluate & $\begin{array}{l}\text { Making an assessment } \\
\text { based on personal } \\
\text { value or view, produce } \\
\text { end products with a } \\
\text { particular purpose, } \\
\text { regardless whether it's } \\
\text { a right or wrong } \\
\text { decision. } \\
\text { Keywords: Evaluate, } \\
\text { Compare, Distinguish, } \\
\text { Conclude, Criticize, } \\
\text { Decide, Defend, } \\
\text { Interpret, and Provide } \\
\text { Justification. }\end{array}$ & $\begin{array}{l}\text { To assess the } \\
\text { validity of the } \\
\text { argument. } \\
\text { To assess the } \\
\text { conclusions to } \\
\text { see whether } \\
\text { certain historical } \\
\text { developments are } \\
\text { desired. }\end{array}$ \\
\hline
\end{tabular}

Adopted from White, P.L (2002).

In order to apply White's ideas in the teaching, it is important for history teacher to plan strategies and techniques for questioning. Wilen (1991) proposes some basic techniques of asking questions; a. Plan all questions in the preparation of lesson plans.

b. Questions should be clear and specific to increase the probability of getting the right answer.

c. Adapt questions to the level of students' ability to improve the probability of answering and thinking correctly

d. The question must be logical and structured to enhance student learning and thinking.

e. The question must consist of low and high levels. Low level question is determined based on the understanding of the questions and students' thinking abilities. Higher level questions required students to think critically and creatively to acquire the answer.

f. Guide students' response and answer to clarify, expand, and elevate their thinking to a higher level.

g. Give students time to think as to encourage a high level of thinking.

h. Questions preferably encourage participation from all students.

i. Encourage and motivate students to respond using their own words.

Drake and Brown (2003) also provide another strategy to increase students' knowledge of the historical facts and students' ability to think towards to Historical Thinking. Both authors suggest to History teachers shoul employ more than one source of teaching material. They recommended the employment of three documents. These documents are called first document, second document and third document. The first document is the main material used in the teaching of History. It can be the History textbook. The teacher should guide the discussion by asking multilevel questions to stimulate students' thinking. The second document either supporting or disputing the content of the first document. It is necessary to have more than one material in the teaching so students may challenge to use their thinking ability to arrive at the decisions. The third document is the document brought by the students in the class which they perceived as the primary source to the topic of discussion. Drake and Brown (2003) stressed that students need to find their own documents related to the topic of discussion. History teacher's role is to ask questions that encouraged the use of Historical Thinking Skills. It is also suggested that students are encouraged to have a group discussion as discussion motivates students to improve their process of thinking. According to Lee and Ahsby (1999), students can achieve a high level of understanding through group discussion that organized by teachers. In addition, the problem-solving process can also be accelerated through discussions which encouraged students' critical thinking skills (Akinoglu, 2003, cited in Cooper and Dilek, 2004).

The application of the two activities mentioned above in the teaching and History learning would help the inculcation of the Historical Thinking Skills. However, it depends on the History teachers' readiness to use the activities. Indeed, the applications of Historical Thinking 
Skills requires a lot of sacrifice in the part of the teachers themselves. They must sacrifice their time to learn, to plan the lesson well and to carry out the teaching in the classroom. More importantly they must sacrifice the culture they are in because to emphasize Historical Thinking Skills in the teaching requires cultural revoke. Besides, the application of Historical Thinking Skills in the teaching would not be materialized meaningfully if the History teachers are not exposed and understood Historical Thinking Skills. Therefore, effort should be given to educate History teachers to perform teaching activities that would encourage the use of students' Historical Thinking Skills

\section{Issues, Problems and Challenges of the applications of Historical Thinking Skills}

Historical Thinking Skills is one of the focus of the History curriculum that mentioned in the SCSS as an initiative to develop thinking skills among students. These skills must be incorporate into teaching and History learning since 2017. The applications of Historical Thinking Skills are not a new proposal on appropriate skills to teach History subjects, but it has been there since 1989 and as one of the vital elements of History discipline in the Integrated Curriculum of Secondary Schools (Centre of Curriculum Development, 2002). However, Historical Thinking Skills never succeed to be an appropriate skill even its documented in the Integrated Curriculum of Secondary Schools or as an old curriculum. Therefore, some issues, problems, and challenges were found in many studies of researchers on the applications of Historical Thinking Skills in teacher's teaching and History learning among students.

The main issue related to the applications of Historical Thinking Skills is History teachers. There are two types of teachers who teach History subjects. First is a teacher who has a background in History education as an option and second is a teacher who has an education background which not History education, but they to teach History subjects as not an option. History teachers should have a brilliant skill to deliver the History lesson in class. However, the teachers who teach History subjects as not an option were incapable to incorporate the Historical Thinking Skills in teaching and Historical learning (Zahara Aziz \& Nik Azleena, 2007; Lisa Yip, 2014; Muhammad Yazid, 2018). Besides, the year of teaching experience such as less than ten years and teachers who never attended the course also shows not significant result on their applications of Historical Thinking Skills in class if compare with teachers who have teaching experience more than ten years and actively attend the courses on History curriculum (Zahara Aziz \& Nik Azleena, 2007; Lisa Yip, 2014; Muhammad Yazid, 2018).
A low level of understanding of the applications of Historical Thinking Skills among History teachers was creating problems in their teaching practice such as incapable to teach their students into high thinking skills and their students have no ability to do activities such as making interpretation, imagination and rationalize the historical facts in History class and influencing students' achievement in History subjects (Kaviza, 2019; Rosy, 2016; Anuar Ahmad \& Nelson Jinggan, 2015; Lisa Yip, 2014; Vieira, TenreiroVieira, \& Martin, 2011; Zahara and Nik Azleena, 2007; Warren, 2007; Hunt, 2000). If History teachers entering the History classes with limited ability in Historical Thinking Skills, then it can be expected that they wil not be able to develop the myriads of skills in their students. Then, they have failed to generate Historical Thinking among the students and never taught their students think critically and creatively, understand the features of history, develop empathy for historical events, explore complex and abstract ideas with the teacher's guidance, and more importantly is understand how historians reconstruct past events using evidence to determine the significance of certain events (Kaviza, 2019; Rosy, 2014).

Students' failure in History subjects is a national issue that reflects on what History teachers doing in classes. Then, History teachers were struggling to make History subjects become favorite subjects among the students with the way to change their teaching practice towards cultivating History Thinking Skills. The challenges for History teachers today are not only to communicate the historical facts about the past events, but also to make those facts alive in the students' lives today (Lowenthal, 2000). Besides, History teachers' ability to take the challenges would nurture students to become empathetic to the History of the country. Without empathy, the younger generation will tend to forget and will not realize the significance of the historical events taught. However, the effectiveness of teaching History subjects need a competence of History teachers in the classroom. The readiness of History teachers in aspects such as knowledge of procedural, pedagogical, using of teaching aids, management in learning activities and teacher's attitude shows teacher's competency towards the application of Historical Thinking Skills, but its mostly on moderate level (Zahara Aziz \& Nik Azleena, 2007; Lisa Yip, 2014; Muhammad Yazid, 2018). Likewise, students' perception towards the applications of Historical Thinking Skills in their History learning mostly on moderate level (Sharifah NorPuteh, Nooreiny Maarul, \& Elisabeth Tak, 2010; Kaviza, 2019). Thus, the high-level of competency among History teachers and students' high perceptions are very important toward the applications of Historical Thinking Skills and as the key to success to bring History subjects at a high standard in the education system of Malaysia. 
If we think about it seriously, the Secondary School Standard Curriculum for History subjects clearly state the application of Historical Thinking Skills is to stimulate high thinking skills among students, but our students have failed even in History class and exam when to answer high-level questions (Kaviza, 2019). This problem occurs when History teachers emphasize only about understanding of the historical facts but not really promoting thinking skills or Historical Thinking to their students. In this case, History teachers only emphasize more on basic understanding such as understanding chronology which is just promoting the Low Thinking Skills to their students (Rosy, 2014). It would not help students to have empathy as intended by the curriculum. Even Warren (2007) agreed the teaching of the events chronology was important and teachers were right in emphasizing it. Unfortunately, students just required to understand and memorize the events based on the chronology. To convince the chronology correct, students were encouraged to explore the textbook to find the evidence. This teaching method was done regularly in teaching of History over the years and not an extraordinary understanding of the chronology. Consequently, students were not exposed on relating the historical events or facts with the present and future events. Students were encouraged to memorize the past events in isolation from the present and future events. Therefore, History teachers never giving opportunities for their students by inculcating the high order thinking skills.

The effort to inculcate Historical Thinking Skills among students can be obtained if History teachers are willing to change their way of teaching in class. However, History teachers are continuing relying only on the History textbook and use it as an explanation in delivering the historical facts (Rosy, 2014). Besides, History textbooks was heavily referred by both teachers and students to get the evidence and points, to give a comprehensive explanation, or to ask and to answer the questions. Besides, History teachers only delivered the contents of the topic according to the History textbook and never referring another source of historical information. Karaagac and Threlfall (2001) have reported that History textbook was very often and the popular reference to be used in the classroom. Unfortunately, History teachers were wholly relying on the textbook as a reference to finding historical information or to deliver the lesson until hindering the applications of Historical Thinking Skills. Therefore, the excessive use of History textbook was left no rooms to refer to other reference books which might stimulate discussion and elicit the high thinking skills.

\section{Conclusion}

As a conclusion, the applications of Historical Thinking Skills in teaching and History learning is rhetorical. History teachers have a lack of understanding of Historical Thinking Skills. An incompetent History teachers in procedural knowledge, pedagogical knowledge, using of teaching aids, management in learning activities and teacher's attitude incorporate Historical Thinking Skills in their teaching practice are the main reason of students have failed to gain Historical Thinking and not acquired the Historical Thinking Skills in their History learning. Besides, History teachers mostly dependent on History textbooks as teaching aids were causing them had not given the opportunities to their students to apply the Historical Thinking Skills. However, students' failure in History subject in SPM examination is the national issue which reflects on how History teachers' teaching practices in class toward Historical Thinking Skills. To make it become reality, History teachers must sacrifice their time to learn, to plan the lesson well and to carry out the teaching towards Historical Thinking Skills in the class. More importantly, History teachers must have the courage to revoke the culture of teaching such as memorization of historical facts through textbooks only by emphasizing the Historical Thinking Skills to their students. The intention to incorporate Historical Thinking Skills implicates the awareness to prepare students to meet with the needs of 21 stcentury education. The 21 st-century education prepares the younger generations to think creatively and critically to address the world's rapid and constant changes. Therefore, Malaysia needs a group of young people who can think globally but have a national spirit, so Historical Thinking can mobilize them towards it.

\section{References}

[1] Abdul Razaq Ahmad. 2010. The Acquisition of Conceptual Understanding of Historical Thinking in the Context of multi-ethnic students in Malaysia. Historia: Jurnal Pendidik dan Peneliti Sejarah, 10(2), 108-119.

[2] Anuar Ahmad dan Nelson Jinggan. 2015. Pengaruh Kompetensi Kemahiran Guru Dalam Pengajaran Terhadap Pencapaian Akademik Pelajar Dalam Mata Pelajaran Sejarah. Jurnal Kurikulum \& Pengajaran Asia Pasifik, Vol.3, No.2, 1-11.

[3] Bain, R.B. 2000. Into the Breach: Using Research and Theory to Shape History Instruction. In Stearns, P.N., Seixas, P. and Wineburg, S. (eds) Knowing Teaching and Learning History: National and International Perspectives. New York: New York Press.

[4] Bloom, B.S. 1956. Taxonomy of Educational Objectives, Handbook I: The Cognitive Domain. New York: David Mckay Co.Inc. 
[5] Centre of Curriculum Development. 2002. Description of KBSM Lesson Syllabus; Form 4 \& 5. Kuala Lumpur: Ministry of Education, Malaysia.

[6] Cooper, H. 2000. The Teaching of History in Primary Schools: Implementing the Revised National Curriculum (3rd ed.). London: David Fulton Publishers Ltd.

[7] Cooper, H and Dilek, D. 2004. Children's Thinking in History: Analysis of a History Lesson Taugh to 11 years Old at Ihsan Sungu School, Istanbul. International Journal of Historical Learning, Teaching and Research, 4(2).

[8] Cuban, L. 2001. Why Bad Reforms Won't Give Us Good School. The American Prospect. 12, Winter. Retrieved from http://www.prospect.org/prin/V12/l/cuban-html [Sept, 03 2019]

[9] Drake, F. and Brown, S.D. 2003. A Systematic Approach to Improve Students' Historical Thinking. The History Techer. 36(4).

[10] Department of Curriculum Development. 2016. Standard Document of Curriculum and Assessment of History Subject Form 1. Putrajaya: Ministry of Education, Malaysia.

[11] Fahim, M. and Masouleh, N.S. 2012. Critical Thinking in Higher Education: A Pedagogical Look. Theory and Practice in Language Studies, Vol.2 (7). 1370-1375.

[12] Fink, N. 2004. Pupil's conceptions of history and history teaching. Analysis, 17,9.

[13]Fisher, R. 1998. Teaching Thinking: Philosophical Enquiry in the Classroom. Cassell: London.

[14]Felder, R.M and Brent, R. 2003. Learning by doing. Chemical engineering education, 37(4), 282-309.

[15] Karaagac, M.K. and Threlfall, J. 2004. The Tension Between Teacher Beliefs and Teacher Practice: The Impact of the Work Setting. Proceeding of the 28th Conference of the International Group for the Psychology of Mathematic Education. 3.137-144.

[16] Kaziva, M. 2019. Hubungan Penerapan Elemen Kemahiran Pemikiran Sejarah dalam Proses Pengajaran dan Pembelajaran terhadap Pencapaian Mata Pelajaran Sejarah dalam kalangan Murid. Jurnal Kurikulum \& Pengajaran Asia Pasifik, Vol.7, 1, 30-38.

[17] Lisa Yip Shukye. 2014. Kajian Tinjauan Kesediaan Guru-guru Sejarah Menerapkan Kemahiran Pemikiran Sejarah dalam kalangan Murid-murid. Jurnal Pendidikan Kent, Bil.13/2014.

[18] Lee, P. and Ashby, R. 1999. The Pittsburg Conference on Teaching, Knowing and Learning History. Teaching History, 97, 13-15.

[19] Lowenthal, D. 2000. Dilemmas and Delights of Learning History. In Stearns, P.N., Seixas, P., and Wineburg, S. (eds) Knowing Teaching and Learning History: National and International Perspectives. New York: New York Press.63-82.
[20] Malaysian Examination Board. 2018. Analysis Reports SPM examination results from 2013 until 2017. Kuala Lumpur: Ministry of Education.

[21] Ministy of Education, Malaysia. 2013. Malaysian Education Development Plan: Preschool Education until Secondary School. Putrajaya: Ministry of Education.

[22] Muhamad Yazid Bin Khalil. 2018. Tahap Pengetahuan Guru Sejarah Sekolah Rendah Dalam Kemahiran Pemikiran Sejarah. Retrieved from https://upikpolimas.edu.my/conference/index.php/icompe x/icompex_2018/paper/viewFile /381/245 [Sept, 15 2019]

[23]Paul, R. 1994. Teaching critical thinking in the strong scene. In S.K. Wlaters (Ed), Re-Thinking Reason: New Perspectives in Critical Thinking. Albany: SUNY Press.

[24] Rosy Talin. 2014. The Teaching of History in Secondary Schools. International Journal of Social Science and Humanities Research, 2(3),723,78.

[25] Schleifer, M. 1997. Philosophy and community education. Analytic teaching, 17(2), 93-100.

[26] Seixas, P. and Peck, C. 2004. Teaching historical thinking. In A. Sears and I. Wright (Eds.), Challenges and Prospect for Canadian Social Studies, 108-117. Vancouver: Pacific Educational Press.

[27] Sharifah NorPuteh, Nooreiny Maarul, \& Elisabeth Tak. 2010. Students' Perception of the Teaching of Historical Thinking Skills. Pertanika Journal Social Science \& Humanities, 18(S), 87-95.

[28] Siti Hawa Abdullah. 2008. Takrif dan Ciri-ciri Pemikiran Sejarah. Pendidikan Sejarah, 9(1), 98-106.

[29] Vieira, R., Tenreiro-Vieira, C., and Martins, I. 2011. Critical thinking: conceptual clarification and its importance in science education. Science Education International, 22(1), 44-54.

[30] Warren, W.J. 2007. Closing the Distance Between Authentic History Pedagogy and Everday Classroom Practice. The History Teacher. 40(2).

[31] Wilen, W.W. 1991. Questioning Skills for teachers. (3rd edition). Washington DC: National Education Association.

[32] Wineburg, S.S. 2000. Making Historical Sense. In Stearns, P.N., Seixas, P. and Wineburg, S. (eds) Knowing Teaching and Learning History: National and International Perspectives. 307-325.

[33] Wineburg, S.S. 2004. Crazy for history. Journal of American History. 90, March.

[34] White, P.L. 2002. Reflections on Forty-Odd years of Teaching History and on Training Prospective PhDs to Do So. The History Teacher. 35(4).

[35] Yeager, E.A. and Foster, S.J. 2001. Why people in the past acted the way they did: An exploratory subject in historical emphathy. Journal of Social Education, 13(2001), 8-24. 
[36]Zahara Aziz \& Nik Azleena Nik Ismail. 2007. Kajian Tinjauan Kesediaan Guru-Guru Sejarah Menerapkan Kemahiran Pemikiran Sejarah Kepada Para Pelajar. Jurnal Pendidikan, 32(2007), 119-137. 